\title{
ANTIDIABETIC AND ENZYMATIC ANTIOXIDANT POTENTIAL FROM ETHANOLIC EXTRACTS OF LEAF AND FRUIT OF TRICHOSANTHES DIOICA AND LEAF OF CLITORIA TERNATEA ON DIABETIC RATS INDUCED BY STREPTOZOTOCIN
}

\author{
KAVITHA R* \\ Department of Biotechnology, Periyar University PG Extension Centre, Dharmapuri - 636 701, Tamil Nadu, India. \\ Email: erokavi_vasu@yahoo.com
}

Received: 26 December 2017, Revised and Accepted: 29 January 2018

ABSTRACT

Objective: To evaluate the antidiabetic and enzymatic antioxidant effects of ethanolic extracts of leaf and fruit of Trichosanthes dioica and leaf of Clitoria ternatea in streptozotocin (STZ)-induced diabetic rats.

Methods: Male adult albino rats of Wistar strain equally divided into 11 groups of six rats each were assigned into non-diabetic and diabetic groups. Diabetes was induced in experimental animals by single dose intraperitoneal administration of STZ at a dose of 60 mg/kg body weight. Group I and II which served as non-diabetic and diabetic controls, respectively, received placebo treatment. The diabetic test Groups III to X were treated with either individual and combined ethanolic extracts of plant materials T. dioica and C. ternatea (200 and $400 \mathrm{mg} / \mathrm{kg}$ bw) and Group XI was treated with glibenclamide $(600 \mu \mathrm{g} / \mathrm{kg}$ bw) for 28 days consecutively. After completion of experimental duration, the animals were sacrificed and collected serum, liver, and kidney were used for the evaluating therapeutic effects on the STZ-induced diabetic rats.

Results: The ethanolic extracts of T. dioica (leaf and fruit) and C. ternatea (leaf) and glibenclamide significantly reduced the levels of lipid peroxidation (LPO) and significantly increased the activities of enzymatic antioxidant markers superoxide dismutase, catalase, and glutathione peroxidase in serum, liver, and kidney of diabetic rats.

Conclusions: From the present study, it can be concluded that the combined extract of $T$. dioica fruit and $C$. ternatea leaf was found to be more effective in treating diabetes and increased activities of enzymatic antioxidants in diabetic-treated rats substantiate that the investigated drugs do extend a clear protective action against LPO in STZ-induced diabetic rats.

Keywords: Trichosanthes dioica, Clitoria ternatea, streptozotocin, Diabetes, Antioxidants.

(C) 2018 The Authors. Published by Innovare Academic Sciences Pvt Ltd. This is an open access article under the CC BY license (http://creativecommons. org/licenses/by/4. 0/) DOI: http://dx.doi.org/10.22159/ajpcr.2018.v11i5.24434

\section{INTRODUCTION}

Diabetes mellitus is a heterogeneous group of disorders characterized by high blood glucose level. This abnormal rise in glucose level in the blood is due to either insulin deficiency or to the resistance of the body's cells to the action of insulin. It is the condition arising due to disorder in the metabolism of carbohydrates, proteins, and fats [1]. With an estimated, 415 million people have diabetes in the world and 78 million people in the Southeast Asia Region. The total number of people in India with diabetes is around 69.2 million (8.7\%) in 2015 [2]. The number is expected to grow to 592 million by 2035. The largest age group currently affected by diabetes is between 40 and 59 years. By 2030 , this "record" is expected to move to the 60-79 age groups with some 196 million cases [3].

Free radicals are biologically important substances which are naturally produced during normal metabolic process in the human body. Increased free radical formation in the body is known as "oxidative stress." The highly reactive radicals can cause oxidative damage to cell components such as DNA, lipids, carbohydrates, and proteins [4]. The generation of free radicals may lead to lipid peroxidation (LPO). Therefore, free radicals result in the development of many diseases such as atherosclerosis, cancer, neurodegenerative diseases, and diabetes. It also plays a pivotal role in the development of diabetic complications both microvascular and macrovascular [5].

Radical scavenging activities are very important due to the deleterious role of free radicals in biological systems. Reactive oxygen species (ROS) are scavenged by antioxidant enzymes. Diabetes also induces changes in the tissue content and activity of the antioxidant enzymes [6].

In modern medicine, no drug is available with satisfactory and effective therapy for the management of diabetes mellitus. Hence, there is a need to search for newer antidiabetic agents having high therapeutic efficacy with minimum side effects. This may be fulfilled by treating diabetes mellitus with plant-derived antidiabetic agents which are being used as traditional medicine because plant-based treatments are safe, economic, accessible, reliable, and highly effective [7]. Certain natural antioxidants present in plants have been shown to reduce oxidative stress and the development of major diseases [8].

Polyherbal therapy is considered the preferred therapeutic approach to the management of diabetes mellitus given its multifactorial pathogenicity. Experience in herbal medicine practice has shown that some antidiabetic drugs failed to be effective alone; they produced wonderful therapeutic results when used in combination [9].

Trichosanthes dioica Roxb. and Clitoria ternatea L. are being used as popular remedy for the treatment of diabetes mellitus in Ayurveda and Siddha medicine. In the present investigation, the first plant $T$. dioica Roxb. belongs to the family Cucurbitaceae. It is a dioecious (male and female) vine (creeper) perennial herb distributed in tropical Asia, Polynesia, and Australia. It is found in the wild plains of North India from Punjab to Assam (Chakravarthy, 1982). It is also extensively cultivated as a vegetable crop in the Eastern part of India. The leaves of the plant are used in constipation, fever, 
skin infection, convalescents, cancer-like conditions, dysentery, diarrhea, bronchitis, and diuretics. The fruits are used as a remedy for spermatorrhea, cooling and laxative [10], diuretic, antiulcerous effects [11], hemagglutinating activities [12]. The plant extract has shown significant reduction in liver marker enzymes, blood urea, and serum creatinine [13], and increased activity of carbohydrate metabolizing enzymes such as glucokinase, pyruvate kinase, and glucose-6-phosphate dehydrogenase [14]

The second plant $C$. ternatea $\mathrm{L}$. is a perennial twining herbaceous plant, belonging to the Fabaceae family. It is found in India, China, Philippines, Bangladesh, and Madagascar. This herb is commonly called "Shankpushpi." The pharmacological properties of $C$. ternatea include antidepressant, anticonvulsant, anti-stress, memory enhancer, and anxiolytic and sedative agent [15]. It has been traditionally used as a remedy for various diseases such as urinogenital disorder, bronchitis, purgative, diuretic, anthelmintic, rheumatism, and diabetes mellitus [16-19]. It is also widely used in the treatment of infertility and gonorrhea [20]

Hence, the objective of the present study is to investigate the abovementioned two different herbs are used individually and in combination to evaluate antidiabetic and enzymatic antioxidant potential on diabetic rats induced by STZ and compared to the effect of standard drug glibenclamide.

\section{METHODS}

\section{Chemicals}

Streptozotocin (STZ) was purchased from Sigma (St. Louis, MO, USA). Glibenclamide was obtained from Aventis Pharmaceuticals Limited (India). All the chemicals and reagents used in the experiments were of analytical grade obtained from BDH (England and India), E.Merck (Germany), Sigma Chemical Company (USA), LOBA Chemie Indo Austranol Co., (India) whenever necessary the solvents were redistilled before use.

\section{Collection and authentication of plant materials}

Fresh unripe fruit and leaf of T. dioica and the leaf of $C$. ternatea were collected from SKM Herbal Research Centre, Erode, Tamil Nadu, India. With the help of local flora, a voucher specimen (No. VOCB 2307 and VOCB 2453) was retained in Ethnopharmacology Unit, Research Department of Botany, V.O.Chidambaram College, Tuticorin, Tamil Nadu, for further reference.

\section{Preparation of the plant extracts}

Freshly collected leaf and fruit of T. dioica and leaf of $C$. ternatea were washed with distilled water, and the fruits were cut into small pieces. Both fruits and leaves were dried under shade for 2 weeks. The shade-dried leaves and fruits were coarsely powdered separately. The powdered materials were kept in airtight containers to use. About $500 \mathrm{~g}$ of dried coarse powdered samples were weighed and subjected to $1250 \mathrm{ml}$ of ethanol in a Soxhlet extractor for $24 \mathrm{~h}$. All the extracts were filtered through Whatman No. 41 filter paper separately, and the extracts were concentrated in vacuum at $60^{\circ} \mathrm{C}$ using a rotary evaporator. To evaporate the remaining solvent, the extracts were kept in an oven at a temperature of $40-50^{\circ} \mathrm{C}$ for $8 \mathrm{~h}$ that were used in the present study.

\section{Preliminary phytochemical screening}

This ethanolic extracts leaf and fruit of T. dioica and leaf of C. ternatea were screened for the presence of various phytochemical constituents such as alkaloids, flavonoids, glycosides, phenols, saponins, steroids, tannins, terpenoids, and fixed oil as described by the standard procedures [21].

\section{Collection of experimental animals}

Healthy male adult albino rats of Wistar strain approximately of same age, weighing around 160-180 g were procured from Nandha College of Pharmacy. The entire process was approved by the Institutional Animal Ethics Committee (IAEC) which is certified by the Committee for the Purpose of Control and Supervision of Experiments on Animals, India
(Proposal number: NCP/IAEC/PHD/01/2007-2008), Nandha College of Pharmacy, Erode, Tamil Nadu, India.

\section{Acute oral toxicity study}

Acute oral toxicity study was performed as per the Organization for Economic Cooperation and Development guidelines 423 (acute toxic class method). After the oral administration of plant extracts, the animals (weighing 160-180 g) were observed individually at least twice daily to find any changes in grooming, hyperactivity, sedation, corneal reflex, urination, salivation, and any mortality during the experimental period of 14 days.

\section{Experimental induction of diabetes}

Diabetes was induced by single dose intraperitoneal administration of STZ at a dose of $60 \mathrm{mg} / \mathrm{kg}$ body weight in $0.1 \mathrm{M}$ citrate buffer ( $\mathrm{pH} 4.5)$ and then injected into the tail of the sixty rats. The injection volume was prepared to contain $1 \mathrm{ml} / \mathrm{kg}$ bw 18 . After $72 \mathrm{~h}$ of STZ administration, the blood glucose content was measured. The animals with blood glucose levels $\geq 250 \mathrm{mg} / \mathrm{dl}$ were considered to be diabetic and used for the experiment

\section{Experimental grouping of animals}

In the present investigation, a total of 66 rats (60 diabetic surviving rats and 6 normal rats) were taken and divided into eleven groups of 6 rats each to determine the antidiabetic and enzymatic antioxidant potential of ethanolic extracts of leaf and fruit of T. dioica and leaf of $C$. ternatea. The actions of the extracts were compared with that of the standard oral hypoglycemic agent, glibenclamide.

Group I: Rats are provided with normal saline for 28 days orally using an intragastric catheter tube (IGC).

Group II: Diabetic rats are provided with normal saline for 28 days orally by IGC.

Group III: Diabetic rats treated with ethanolic leaf extract of $T$. dioica at the dose of $200 \mathrm{mg} / \mathrm{kg}$ bw, orally for 28 days consecutively by IGC.

Group IV: Diabetic rats treated with ethanolic leaf extract of T. dioica at the dose of $400 \mathrm{mg} / \mathrm{kg}$ bw, orally for 28 days consecutively by IGC.

Group V: Diabetic rats treated with ethanolic fruit extract of $T$. dioica at the dose of $200 \mathrm{mg} / \mathrm{kg}$ bw, orally for 28 days consecutively by IGC.

Group VI: Diabetic rats treated with ethanolic fruit extract of $T$. dioica at the dose of $400 \mathrm{mg} / \mathrm{kg}$ bw, orally for 28 days consecutively by IGC.

Group VII: Diabetic rats treated with ethanolic leaf extract of $C$. ternatea at the dose of $200 \mathrm{mg} / \mathrm{kg}$ bw, orally for 28 days consecutively by IGC.

Group VIII: Diabetic rats treated with ethanolic leaf extract of $C$. ternatea at the dose of $400 \mathrm{mg} / \mathrm{kg} \mathrm{bw}$, orally for 28 days consecutively by IGC.

Group IX: Diabetic rats treated with combined ethanolic leaf extract of $T$. dioica at the dose of $200 \mathrm{mg} / \mathrm{kg}$ bw and leaf extract of $C$. ternatea at the dose of $200 \mathrm{mg} / \mathrm{kg} \mathrm{bw}$, orally for 28 days consecutively by IGC

Group X: Diabetic rats treated with combined ethanolic fruit extract of T. dioica at the dose of $200 \mathrm{mg} / \mathrm{kg}$ bw and leaf extract of $C$. ternatea at the dose of $200 \mathrm{mg} / \mathrm{kg}$ bw, orally for 28 days consecutively by IGC.

Group XI: Diabetic rats treated with standard drug glibenclamide at the dose of $600 \mu \mathrm{g} / \mathrm{kg}$ bw, orally for 28 days consecutively by IGC.

\section{Preparation of plant extract for dosing}

The plant extracts used for the study was suspended each time with $1 \%$ $(\mathrm{W} / \mathrm{V})$ solution of $0.1 \%$ ethanol before administration.

\section{Preparation of known drug for dosing}

Glibenclamide is used as a standard antidiabetic drug in STZ-induced moderate diabetes to compare the antidiabetic properties of a variety of hypoglycemic compounds. It was preserved at room temperature. 
The tablets were crushed, suspended in distilled water, and used during $28 \mathrm{~d}$ treatment period at $0.6 \mathrm{mg} / \mathrm{kg}$ bw/day. The administered dose was calculated equivalent to the human therapeutic dose according to the Food and Drug Administration. All the drug treatments were given between 9.30 and $10.00 \mathrm{am}$.

Collection of blood and preparation of tissue homogenate

At the end of the treatment, all rats were sacrificed by cervical dislocation. Blood was collected from the experimental animals by direct cardiac puncture. Serum and plasma were separated by centrifugation at $2500 \mathrm{rpm}$ for $10 \mathrm{~min}$ and stored at $-20^{\circ} \mathrm{C}$ until used for the enzyme and biochemical assays. Liver and kidney of the sacrificed animals were excised immediately and thoroughly washed with ice-cold physiological saline and kept in deep freezer at $-20^{\circ} \mathrm{C}$ till used. The homogenate was filtered and then centrifuged at $10,000 \mathrm{rpm}$ for $20 \mathrm{~min}$ at $4^{\circ} \mathrm{C}$.

\section{Measurement of biochemical parameters}

Determination of blood glucose

Oral glucose tolerance test (OGTT) was performed by the method [22] and blood glucose was determined according to the method [23].

\section{Determination of oxidative stress markers in serum, hepatic, and kidney tissues}

The lipid peroxidation was estimated by measuring thiobarbituric acid reactive substances (TBARS) according to the method [24]

Tissue slices were homogenized in ice cold $1.15 \% \mathrm{KCl} 0.5 \mathrm{ml}$ of aliquot of the serum sample $/ 0.5 \mathrm{ml}$ of tissue homogenate were mixed with 3 $\mathrm{ml}$ of $1 \%$ phosphoric acid and $1 \mathrm{ml}$ of $0.6 \%$ thiobarbituric acid. The mixture was heated for $45 \mathrm{~min}$ in a boiling water bath and after addition of $4 \mathrm{ml}$ of $\mathrm{n}$-butanol vigorously, vortexed and centrifuged at $2000 \mathrm{rpm}$ for $20 \mathrm{~min}$. The absorbance of the upper organic layer at $535 \mathrm{~nm}$ was measured in a spectrophotometer and compared with a standard of freshly prepared 1,1,3,3 tetraethoxy propane at concentration of $5.125,10.25$ and $20.5 \mathrm{nmol} / \mathrm{ml}$ using an extinction coefficient of the chromophore $1.56 \times 10^{-5} \mathrm{M} / \mathrm{cm}$. The results were expressed as nmol/ mg protein in serum and $\mu$ moles of MDA formed/ min/ mg protein in tissue.

Superoxide dismutase (SOD) was investigated by the method [25]

Assay mixture contained $1.2 \mathrm{ml}$ of sodium pyrophosphate, 0.1 $\mathrm{ml}$ of phenazine methosulphate, $0.3 \mathrm{ml}$ of NBT and $0.2 \mathrm{ml}$ of $\mathrm{NADH}$, appropriately diluted enzyme preparation $(0.5 \mathrm{ml}$ of tissue homogenate $0.5 \mathrm{ml}$ of serum) and water in a total volume of $3 \mathrm{ml}$. Reaction was started by the addition of NADH. After incubation at $30^{\circ} \mathrm{C}$ for $90 \mathrm{sec}$. the reaction was stopped by the addition of $1 \mathrm{ml}$ glacial acetic acid. Reaction mixture was stirred vigorously and shaken with $4 \mathrm{ml}$ of n-butanol. The mixture was allowed to stand for $10 \mathrm{~min}$, centrifuged at $2000 \times g$ for $10 \mathrm{~min}$ and the butanol layer was collected. The colour intensity of the chromogen in the butanol layer was measured at 560 $\mathrm{nm}$ against butanol. A system devoid of the enzyme served as control. The enzyme activity was expressed as $50 \%$ inhibition of NBT reduction/ $\mathrm{min} / \mathrm{mg}$ protein.

Table 1: Phytochemical screening of ethanolic extracts of leaf and fruit of $T$. dioica and leaf of $C$. ternatea

\begin{tabular}{llll}
\hline Phytochemicals & \multicolumn{2}{l}{ T. dioica } & \multirow{2}{*}{ C. ternatea Leaf } \\
\cline { 2 - 3 } & Leaf & Fruit & \\
\hline Alkaloids & + & + & - \\
Flavonoids & + & + & + \\
Glycosides & - & - & + \\
Phenols & + & + & + \\
Saponins & + & + & - \\
Steroids & + & + & + \\
Tannins & + & + & + \\
Triterpenoids & - & - & + \\
Fixed oil & - & - & - \\
\hline
\end{tabular}

+: Present, -: Absent, T. dioica: Trichosanthes dioica, C. ternatea: Clitoria ternatea
Catalase (CAT) [26]

The assay mixture contained $0.5 \mathrm{ml}$ of $0.2 \mathrm{M} \mathrm{H}_{2} \mathrm{O}_{2}, 1 \mathrm{ml}$ of phosphate buffer and $0.4 \mathrm{ml}$ of water. $0.2 \mathrm{ml}$ of tissue homogenate / $0.2 \mathrm{ml}$ of serum were added to initiate the reaction. $2 \mathrm{ml}$ of the dichromate/acetic acid reagent was added after $0,30,60$ and 90 seconds of incubation. To the control tube the enzyme was added after the addition of the acid reagent. The test tubes were kept in boiling water bath $\left(60^{\circ} \mathrm{C}\right)$ for $10 \mathrm{~min}$ and then cooled. The colour developed was read at $620 \mathrm{~nm}$ against a reagent blank in UV-visible spectrophotometer. Standards of $\mathrm{H}_{2} \mathrm{O}_{2}$ in the range of 2-10 $\mu \mathrm{M}$ were taken and preceded as test with blank containing reagent alone. The activity of catalase was expressed as $\mu$ mole of $\mathrm{H}_{2} \mathrm{O}_{2}$ consumed/ $\mathrm{min} / \mathrm{mg}$ protein.

Glutathione peroxidase (GPx) were determined by the method [27] Briefly, $4 \mathrm{ml}$ of buffer, $0.1 \mathrm{ml}$ of sodium azide, $0.2 \mathrm{ml}$ of reduced glutathione, $0.1 \mathrm{ml}$ of $\mathrm{H}_{2} \mathrm{O}_{2}, 0.2 \mathrm{ml}$ of tissue homogenate $/ 0.2 \mathrm{ml}$ of serum and $1 \mathrm{ml}$ of water were added to a final incubation volume of $2 \mathrm{ml}$. The tubes were incubated for $0,30,60,90 \mathrm{sec}$. The reaction was terminated by the addition of $0.5 \mathrm{ml}$ TCA. To determine the glutathione content, $2 \mathrm{ml}$ of the supernatant was removed by centrifugation at $3200 \times g$ for $20 \mathrm{~min}$ and added $3 \mathrm{ml}$ disodium hydrogen phosphate solution and $1 \mathrm{ml}$ of DTNB reagent. The colour developed was read at $412 \mathrm{~nm}$. Standards in the range of 200-1000 $\mu \mathrm{g}$ were taken and treated in the similar manner. The activity of GPx was expressed in terms of Umol/mg protein for serum and $\mu$ moles of glutathione oxidized $/ \mathrm{min} / \mathrm{mg}$ protein for tissue homogenate.

\section{Statistical analysis}

All the experimental values are expressed as means \pm standard deviation for groups of six animals each. Statistical analyses were performed by Student's t-test. The values are statistically significant at three levels, that is, ${ }^{* * *} \mathrm{p}<0.001,{ }^{* *} \mathrm{p}<0.01$, and ${ }^{*} \mathrm{p}<0.05$, but non-significant if $\mathrm{p}>0.05$.

\section{RESULTS}

\section{Preliminary phytochemical screening}

The distribution of different phytochemical constituents in ethanolic extract of leaf and fruit of T. dioica and leaf of $C$. ternatea were evaluated qualitatively and shown in Table 1.

From the Table 1, it was evident that a wide range of active compounds were present in ethanolic extracts of all the above-said plants.

\section{Acute oral toxicity study}

Acute oral toxicity studies revealed the non-toxic nature of ethanolic extracts of leaf and fruit of T. dioica and leaf of C. ternatea as the treated rats appeared normal and did not display any significant changes such as irritability, tremor, labored breathing, staggering and convulsion up to a concentration of $800 \mathrm{mg} / \mathrm{kg}$ bw. Poor activities were seen in animals treated with ethanolic extracts of leaf and fruit of $T$. dioica at a concentration of $2000 \mathrm{mg} / \mathrm{kg}$ bw. The same condition was noted at $1600 \mathrm{mg} / \mathrm{kg}$ bw in C. ternatea leaf-treated animals, whereas very poor activities were seen at $2000 \mathrm{mg} / \mathrm{kg}$ bw. There was no mortality or toxicity reaction at any of the doses until the end of the study.

\section{Effect of ethanolic extracts of leaf and fruit of T. dioica and leaf of} C. ternatea on OGTT

The blood glucose level of normal control rats reached maximum during first $60 \mathrm{~min}$ following glucose intake $(2 \mathrm{~g} / \mathrm{kg} \mathrm{bw})$. At the end of $3 \mathrm{~h}$, the blood glucose level in normal control rats returned back near normal level. At the same time in diabetic control rats, it was found to be $312.25 \pm 6.32 \mathrm{mg} / \mathrm{dl}$. After the administration of the plant extracts and glibenclamide, the blood glucose levels were decreased significantly $(p<0.01$ and $p<0.05)$ in STZ-induced diabetic rats. The result of OGTT was revealed in illustrated in Table 2 .

Effect of ethanolic extracts of leaf and fruit of $T$. dioica and leaf of C. ternatea on blood glucose level in STZ-induced diabetic rats The diabetic rats (Group II) showed a significant increase in blood glucose $(\mathrm{p}<0.001)$ compared with normal control rats (Group I). The ethanolic extracts of individual, combined extracts, and known drugtreated groups showed a significant $(p<0.05 ; p<0.01)$ decrease in the blood glucose level in diabetic-treated rats (Table 3 ). 
Effect of ethanolic extracts of leaf and fruit of $T$. dioica and leaf of C. ternatea on serum, liver, and kidney LPO in STZ-induced diabetic rats

The levels of LPO in serum, liver, and kidney were markedly elevated $(\mathrm{p}<0.01)$ in STZ-induced diabetic rats (Group II) in comparison with normal control rats (Group I). Higher dose of T. dioica (Group IV), higher and lower dose of $C$. ternatea leaf (Group VII and Group VIII)-treated groups moderately $(\mathrm{p}<0.05)$ decreased serum LPO, and higher dose of T. dioica fruit (Group VI) combined extract-treated groups (Group IX and $\mathrm{X})$ demonstrated significant $(\mathrm{p}<0.01)$ decrease of LPO level in serum and tissues of STZ-induced diabetic rats. The standard drugtreated group (Group XI) had significantly $(\mathrm{p}<0.05)$ decreased serum LPO and significant $(\mathrm{p}<0.01)$ decrease in tissue LPO (Table 4).
Effect of ethanolic extracts of leaf and fruit of $T$. dioica and leaf of $C$. ternatea on serum, liver, and kidney enzymatic antioxidant levels in STZ-induced diabetic rats

SOD

Table 5 showed the levels of SOD in serum, liver, and kidney of normal and diabetic rats.

As expected, the leveld of SOD in serum, liver, and kidney were significantly $(\mathrm{p}<0.01)$ decreased in STZ-induced diabetic rats when compared with normal control rats. There was a significant $(\mathrm{p}<0.05)$ increase in SOD level in all the plant extract-treated groups. Among these groups, significant $(\mathrm{p}<0.01)$ increase in liver SOD (Groups IX) and

Table 2: Effect of ethanolic extracts of leaf and fruit of $T$. dioica and leaf of $C$. ternatea on blood glucose levels in glucose-loaded hyperglycemic (OGTT) rats

\begin{tabular}{|c|c|c|c|c|c|c|}
\hline \multirow[t]{4}{*}{ Time (min) } & \multicolumn{6}{|c|}{ Blood glucose level (mg/dl) } \\
\hline & \multirow[t]{3}{*}{ Normal control } & \multirow[t]{3}{*}{ Diabetic control } & \multicolumn{3}{|c|}{ Dose (400 mg/kg bw) } & \multirow[t]{3}{*}{ Glibenclamide $(0.6 \mathrm{mg} / \mathrm{kg} \mathrm{bw})$} \\
\hline & & & \multicolumn{2}{|l|}{ T. dioica } & \multirow[t]{2}{*}{ C. ternatea leaf } & \\
\hline & & & Leaf & Fruit & & \\
\hline 0 & $101.64 \pm 3.22$ & $198.25 \pm 4.27^{* *}$ & $214.96 \pm 7.24^{* *}$ & $204.26 \pm 4.14^{* *}$ & $223.04 \pm 4.67^{* *}$ & $198.17 \pm 4.29 * *$ \\
\hline 30 & $142.15 \pm 4.25$ & $216.54 \pm 5.38^{* *}$ & $205.17 \pm 6.68^{*}$ & $195.27 \pm 5.38 *$ & $207.17 \pm 2.85^{* *}$ & $188.32 \pm 4.94^{*}$ \\
\hline 120 & $124.34 \pm 2.13$ & $268.95 \pm 3.85^{* *}$ & $162.65 \pm 6.03^{*}$ & $142.35 \pm 2.83^{\mathrm{NS}}$ & $154.37 \pm 5.24^{\mathrm{NS}}$ & $141.74 \pm 5.37^{*}$ \\
\hline 180 & $102.11 \pm 2.51$ & $312.25 \pm 6.32^{* * *}$ & $116.55 \pm 5.34^{\mathrm{a}}$ & $108.25 \pm 4.34^{\text {aa }}$ & $101.74 \pm 3.38^{\text {aa }}$ & $104.19 \pm 4.97 *$ \\
\hline
\end{tabular}

Values are reported as mean \pm SD for six animals in each group. ${ }^{*} \mathrm{p}<0.05,{ }^{* *} \mathrm{p}<0.01,{ }^{* * *} \mathrm{p}<0.001$ significance between normal control versus diabetic control and drug-treated groups; ${ }^{a} \mathrm{p}<0.05$, ${ }^{\text {aa }} \mathrm{p}<0.01$ significance between diabetic control versus drug-treated groups; NS: Not significant, SD: Standard deviation,

T. dioica: Trichosanthes dioica, C. ternatea: Clitoria ternatea, OGTT: Oral glucose tolerance test

Table 3: Effect of ethanolic extracts of leaf and fruit of T. dioica and leaf of $C$. ternatea on blood glucose in control and experimental rat

\begin{tabular}{|c|c|c|}
\hline Treatment groups & Dose (mg/kg bw) & Blood glucose (mg/dl) \\
\hline I. Normal control & Normal saline & $79.56 \pm 3.21$ \\
\hline II. Diabetic control & Normal saline & $214.55 \pm 16.59^{* * *}$ \\
\hline III. Diabetic $+T$. dioica leaf & 200 & $131.56 \pm 3.93^{*}$ \\
\hline IV. Diabetic + T. dioica leaf & 400 & $121.33 \pm 4.16^{\mathrm{a}}$ \\
\hline V. Diabetic+T. dioica fruit & 200 & $108.16 \pm 3.26^{\mathrm{a}}$ \\
\hline VI. Diabetic+T. dioica fruit & 400 & $92.11 \pm 2.86^{\mathrm{aa}}$ \\
\hline VII. Diabetic $+C$. ternatea leaf & 200 & $112.16 \pm 2.92^{\mathrm{a}}$ \\
\hline IX. Diabetic $+T$. dioica leaf $+C$. ternatea leaf & $200+200$ & $92.11 \pm 1.94^{\text {aa }}$ \\
\hline X. Diabetic + T. dioica fruit $+C$. ternatea leaf & $200+200$ & $73.28 \pm 1.84^{\mathrm{a}}$ \\
\hline XI. Diabetic+Glibenclamide & 0.6 & $79.16 \pm 1.93^{a}$ \\
\hline
\end{tabular}

Values are reported as mean \pm SD for six animals in each group. ${ }^{*} \mathrm{p}<0.05,{ }^{* *} \mathrm{p}<0.01,{ }^{* * *} \mathrm{p}<0.001$ significance between normal control versus diabetic control and drug-treated groups; ${ }^{\mathrm{a}} \mathrm{p}<0.05$, aa $\mathrm{p}<0.01$ significance between diabetic control versus drug-treated groups; NS: Not significant, SD: Standard deviation, T. dioica: Trichosanthes dioica, C. ternatea: Clitoria ternatea

Table 4: Effect of ethanolic extracts of leaf and fruit of $T$. dioica and leaf of $C$. ternatea on lipid peroxidation in serum, liver, and kidney of control and experimental rats

\begin{tabular}{|c|c|c|c|c|}
\hline \multirow[t]{2}{*}{ Treatment groups } & \multirow[t]{2}{*}{ Dose (mg/kg bw) } & \multicolumn{3}{|c|}{ Lipid peroxidation (units/mg protein) } \\
\hline & & Serum $\#$ & Liver $\#$ & Kidney $^{\# \#}$ \\
\hline I. Normal control & Normal saline & $1.73 \pm 0.04$ & $0.093 \pm 0.014$ & $0.719 \pm 0.012$ \\
\hline III. Diabetic + T. dioica leaf & 200 & $2.16 \pm 0.12^{\mathrm{NS}}$ & $0.162 \pm 0.011^{*}$ & $1.102 \pm 0.017$ \\
\hline IV. Diabetic+T. dioica leaf & 400 & $1.93 \pm 0.11^{\mathrm{a}}$ & $0.151 \pm 0.014^{*}$ & $0.802 \pm 0.052^{\mathrm{a}}$ \\
\hline V. Diabetic+T. dioica fruit & 200 & $1.91 . \pm 0.17^{\mathrm{a}}$ & $0.183 \pm 0.017 *$ & $1.117 \pm 0.046$ \\
\hline VI. Diabetic+T. dioica fruit & 400 & $1.69 \pm 0.14^{\mathrm{aa}}$ & $0.162 \pm 0.013^{*}$ & $0.932 \pm 0.024^{\mathrm{a}}$ \\
\hline VII. Diabetic $+C$. ternatea leaf & 200 & $1.83 \pm 0.11^{\mathrm{a}}$ & $0.101 \pm 0.017^{\mathrm{a}}$ & $1.001 \pm 0.071^{\mathrm{a}}$ \\
\hline VIII. Diabetic $+C$. ternatea leaf & 400 & $1.71 \pm 0.13^{\mathrm{a}}$ & $0.099 \pm 0.026^{\mathrm{aa}}$ & $0.736 \pm 0.022^{\text {aa }}$ \\
\hline IX. Diabetic $+T$. dioica leaf $+C$. ternatea leaf & $200+200$ & $1.63 \pm 0.21^{\text {aa }}$ & $0.084 \pm 0.051^{\text {aa }}$ & $0.702 \pm 0.053^{\text {aa }}$ \\
\hline X. Diabetic $+T$. dioica fruit $+C$. ternatea leaf & $200+200$ & $1.51 \pm 0.17^{\text {aa }}$ & $0.079 \pm 0.046^{\text {aa }}$ & $0.736 \pm 0.021^{\text {aa }}$ \\
\hline XI. Diabetic+Glibenclamide & 0.6 & $1.76 \pm 0.12^{\mathrm{a}}$ & $0.098 \pm 0.013^{\text {aa }}$ & $0.792 \pm 0.047^{\text {aa }}$ \\
\hline
\end{tabular}

Values are reported as mean \pm SD for six animals in each group. ${ }^{*} \mathrm{p}<0.05,{ }^{* *} \mathrm{p}<0.01,{ }^{* * *} \mathrm{p}<0.001$ significance between normal control versus diabetic control

and drug-treated groups; ${ }^{\mathrm{a}} \mathrm{p}<0.05$, aa $\mathrm{p}<0.01$ significance between diabetic control versus drug-treated groups; NS: Not significant, SD: Standard deviation,

T. dioica: Trichosanthes dioica, C. ternatea: Clitoria ternatea. \#Units=nmoles/mg protein. \#\#Units=nmoles of malondialdehyde formed/min 
kidney SOD (Group XI) were recorded when compared with diabetic control group.

\section{CAT}

As predicted the level of CAT in serum, liver, and kidney were significantly $(\mathrm{p}<0.05)$ decreased in STZ-induced diabetic rats (Group II) when compared with normal control rats (Group I). There was a significant $(\mathrm{p}<0.05 ; \mathrm{p}<0.01)$ increase in CAT in all the plant extract- treated groups except low dose of leaf extracts (Group V and VII) which were dose-dependent. The known drug-treated group (Group XI) recorded enzyme levels to near normal when compared with diabetic control group (Table 6).

$G P x$

GPx activity was significantly $(\mathrm{p}<0.01 ; \mathrm{p}<0.05)$ reduced in STZ-treated diabetic group when compared to control group. Oral administration

Table 5: Effect of ethanolic extracts of leaf and fruit of T. dioica and leaf of $C$. ternatea on superoxide dismutase in serum, liver, and kidney of control and experimental rats

\begin{tabular}{|c|c|c|c|c|}
\hline \multirow[t]{2}{*}{ Treatment groups } & \multirow[t]{2}{*}{ Dose (mg/kg bw) } & \multicolumn{3}{|c|}{ SOD (units/mg protein) } \\
\hline & & Serum & Liver & Kidney \\
\hline I. Normal control & Normal saline & $453.51 \pm 29.14$ & $4.98 \pm 0.83$ & $14.87 \pm 1.26$ \\
\hline III. Diabetic $+T$. dioica leaf & 200 & $298.31 \pm 21.17 *$ & $3.94 \pm 0.56$ & $9.89 \pm 0.82$ \\
\hline IV. Diabetic+T. dioica leaf & 400 & $337.21 \pm 22.36^{\mathrm{a}}$ & $4.04 \pm 0.14$ & $11.57 \pm 1.11^{\mathrm{a}}$ \\
\hline V. Diabetic+T. dioica fruit & 200 & $356.51 \pm 23.99^{a}$ & $4.24 \pm 0.11$ & $8.14 \pm 1.06$ \\
\hline VI. Diabetic+T. dioica fruit & 400 & $389.16 \pm 20.13^{\mathrm{a}}$ & $4.72 \pm 0.28^{\mathrm{a}}$ & $13.87 \pm 1.42$ \\
\hline VII. Diabetic $+C$. ternatea leaf & 200 & $366.51 \pm 23.29$ & $3.91 \pm 0.14$ & $10.89 \pm 1.48^{\mathrm{a}}$ \\
\hline VIII. Diabetic $+C$. ternatea leaf & 400 & $419.31 \pm 27.56^{\mathrm{a}}$ & $4.76 \pm 0.12^{\mathrm{a}}$ & $14.13 \pm 1.32^{\text {aa }}$ \\
\hline IX. Diabetic $+T$. dioica leaf $+C$. ternatea leaf & $200+200$ & $423.14 \pm 28.34^{\mathrm{a}}$ & $4.87 \pm 0.31^{\mathrm{a}}$ & $16.04 \pm 1.55^{\mathrm{a}}$ \\
\hline X. Diabetic $+T$. dioica fruit $+C$. ternatea leaf & $200+200$ & $443.56 \pm 24.91^{\mathrm{a}}$ & $5.26 \pm 0.73^{\text {aа }}$ & $15.78 \pm 1.67^{\mathrm{a}}$ \\
\hline XI. Diabetic+Glibenclamide & 0.6 & $439.53 \pm 21.3^{\text {aa }}$ & $4.88 \pm 0.63^{\mathrm{a}}$ & $15.92 \pm 1.83^{\text {aа }}$ \\
\hline
\end{tabular}

Values are reported as mean \pm SD for six animals in each group. ${ }^{*} \mathrm{p}<0.05,{ }^{* *} \mathrm{p}<0.01,{ }^{* * *} \mathrm{p}<0.001$ significance between normal control versus diabetic control and drug-treated groups; ${ }^{a} \mathrm{p}<0.05$, ${ }^{a} \mathrm{p}<0.01$ significance between diabetic control versus drug-treated groups; NS: Not significant, SD: Standard deviation, T. dioica: Trichosanthes dioica, C. ternatea: Clitoria ternatea, SOD: Superoxide dismutase. Units $=50 \%$ inhibition of nitro blue tetrazolium reduction/min

Table 6: Effect of ethanolic extracts of leaf and fruit of $T$. dioica and leaf of $C$. ternatea on catalase in serum, liver, and kidney of control and experimental rats

\begin{tabular}{|c|c|c|c|c|}
\hline \multirow[t]{2}{*}{ Treatment groups } & \multirow[t]{2}{*}{ Dose (mg/kg bw) } & \multicolumn{3}{|c|}{ CAT (units/mg protein) } \\
\hline & & Serum & Liver & Kidney \\
\hline I. Normal control & Normal saline & $81.56 \pm 2.31$ & $86.24 \pm 2.56$ & $46.32 \pm 2.34$ \\
\hline III. Diabetic + T. dioica leaf & 200 & $72.14 \pm 1.73$ & $71.29 \pm 2.38^{\mathrm{a}}$ & $32.17 \pm 2.16^{\mathrm{a}}$ \\
\hline IV. Diabetic $+T$. dioica leaf & 400 & $80.33 \pm 1.84$ & $78.41 \pm 2.56^{\mathrm{a}}$ & $39.83 \pm 2.78^{\mathrm{a}}$ \\
\hline V. Diabetic+T. dioica fruit & 200 & $78.56 \pm 1.36$ & $79.11 \pm 2.36^{\mathrm{a}}$ & $29.82 \pm 3.56^{\mathrm{NS}}$ \\
\hline VI. Diabetic+T. dioica fruit & 400 & $82.11 \pm 1.39^{\mathrm{a}}$ & $85.61 \pm 3.14^{\mathrm{aa}}$ & $41.32 \pm 3.14^{\text {aa }}$ \\
\hline VII. Diabetic $+C$. ternatea leaf & 200 & $73.14 \pm 1.22^{\mathrm{NS}}$ & $76.56 \pm 2.93^{\mathrm{a}}$ & $27.92 \pm 2.18^{\mathrm{NS}}$ \\
\hline VIII. Diabetic $+C$. ternatea leaf & 400 & $78.94 \pm 1.39^{\mathrm{a}}$ & $83.66 \pm 3.26^{\mathrm{aa}}$ & $38.57 \pm 2.62^{\text {aa }}$ \\
\hline IX. Diabetic $+T$. dioica leaf $+C$. ternatea leaf & $200+200$ & $80.04 \pm 1.13^{\mathrm{a}}$ & $84.59 \pm 3.56^{\mathrm{aa}}$ & $44.85 \pm 3.76^{\text {aa }}$ \\
\hline X. Diabetic + T. dioica fruit $+C$. ternatea leaf & $200+200$ & $84.66 \pm 1.22^{\mathrm{a}}$ & $81.66 \pm 2.91^{\text {aa }}$ & $41.37 \pm 3.53^{\text {aa }}$ \\
\hline XI. Diabetic+Glibenclamide & 0.6 & $78.31 \pm 0.08^{\mathrm{a}}$ & $84.29 \pm 2.19^{\text {aa }}$ & $45.42 \pm 2.37^{\text {aa }}$ \\
\hline
\end{tabular}

Values are reported as mean \pm SD for six animals in each group. ${ }^{*} \mathrm{p}<0.05,{ }^{* *} \mathrm{p}<0.01,{ }^{* * *} \mathrm{p}<0.001$ significance between normal control versus diabetic control and drug-treated groups; ${ }^{\mathrm{a}} \mathrm{p}<0.05$, aa $\mathrm{p}<0.01$ significance between diabetic control versus drug-treated groups; NS: Not significant, SD: Standard deviation,

T. dioica: Trichosanthes dioica, C. ternatea: Clitoria ternatea, CAT: Catalase. Units $=\mu$ moles of hydrogen peroxide consumed $/ \mathrm{min}$

Table 7: Effect of ethanolic extracts of leaf and fruit of $T$. dioica and leaf of $C$. ternatea on glutathione peroxidase in serum, liver, and kidney of control and experimental rats

\begin{tabular}{|c|c|c|c|c|}
\hline \multirow[t]{2}{*}{ Treatment groups } & \multirow[t]{2}{*}{ Dose (mg/kg bw) } & \multicolumn{3}{|l|}{ GPx } \\
\hline & & Serum\# & Liver\#\# & Kidney\#\# \\
\hline I. Normal control & Normal saline & $641.31 \pm 34.16$ & $7.99 \pm 0.14$ & $5.86 \pm 1.35$ \\
\hline III. Diabetic $+T$. dioica leaf & 200 & $493.21 \pm 21.46^{*}$ & $4.56 \pm 0.21^{*}$ & $2.78 \pm 0.42$ \\
\hline IV. Diabetic+T. dioica leaf & 400 & $569.56 \pm 23.56^{\mathrm{a}}$ & $6.94 \pm 0.53$ & $4.13 \pm 1.22^{\mathrm{a}}$ \\
\hline V. Diabetic+T. dioica fruit & 200 & $523.21 \pm 30.14^{*}$ & $5.21 \pm 0.39 *$ & $2.61 \pm 1.06$ \\
\hline VI. Diabetic+T. dioica fruit & 400 & $596.56 \pm 29.31^{\mathrm{a}}$ & $7.29 \pm 0.33^{\mathrm{a}}$ & $3.16 \pm 1.32^{\mathrm{a}}$ \\
\hline VII. Diabetic $+C$. ternatea leaf & 200 & $588.59 \pm 26.14^{\mathrm{a}}$ & $6.68 \pm 0.14^{\mathrm{NS}}$ & $3.07 \pm 1.27$ \\
\hline VIII. Diabetic $+C$. ternatea leaf & 400 & $603.69 \pm 21.56^{\text {aa }}$ & $7.83 \pm 0.56^{\mathrm{aa}}$ & $5.19 \pm 1.72^{\text {aa }}$ \\
\hline IX. Diabetic $+T$. dioica leaf $+C$. ternatea leaf & $200+200$ & $611.39 \pm 29.91^{\mathrm{a}}$ & $7.89 \pm 0.57$ & $4.88 \pm 1.24^{\mathrm{a}}$ \\
\hline X. Diabetic $+T$. dioica fruit $+C$. ternatea leaf & $200+200$ & $633.84 \pm 22.36^{\text {aa }}$ & $7.31 \pm 0.14^{\text {aa }}$ & $4.16 \pm 1.63^{a}$ \\
\hline XI. Diabetic+Glibenclamide & 0.6 & $611.93 \pm 24.63^{\mathrm{a}}$ & $7.31 \pm 0.56$ & $5.78 \pm 1.37^{\text {aa }}$ \\
\hline
\end{tabular}

Values are reported as mean \pm SD for six animals in each group. ${ }^{*} \mathrm{p}<0.05,{ }^{* *} \mathrm{p}<0.01,{ }^{* * *} \mathrm{p}<0.001$ significance between normal control versus diabetic control and drug-treated groups; ${ }^{\mathrm{a}} \mathrm{p}<0.05$, aa $\mathrm{p}<0.01$ significance between diabetic control versus drug-treated groups; NS: Not significant, SD: Standard deviation,

T. dioica: Trichosanthes dioica, C. ternatea: Clitoria ternatea, GPx: Glutathione peroxidase. \#Umol/mg protein; \#\# $\mu$ moles of glutathione oxidized/min/mg protein 
of ethanolic extracts of leaf and fruit of T. dioica and leaf of $C$. ternatea restored the activities of GPx significantly $(\mathrm{p}<0.01 ; \mathrm{p}<0.05)$. GPx activity was found to be dose-dependent. The standard drug had significantly increased kidney GPx levels (Table 7).

\section{DISCUSSION}

The phytochemical screening is one of the tools for the quality assessment. The presence or absence of certain important bioactive compounds in an extract is determined by color reactions of the compounds with specific chemicals which act as dyes.

In India, traditional communities like tribal and rural populations are frequently using the crude extracts of local plants for medicinal and other purposes. The first step toward this purpose is the biological and phytochemical screening of plant extracts from traditional preparations used in popular medicine. The phytocompounds are well known to have curative activity against several human problems such as diuretics, skin diseases [28], hypercholesterolemia, and hyperglycemic disorders [29] and therefore could suggest the folk use of the medicinal plants.

In the present study, the occurrences of wide range of active phytocompounds were seen in ethanolic extract. Ethanol is one of the good solvents in plant extractions which include low toxicity, easy evaporation at low heat, preservative action, and inability to cause the extract to complex or dissociate.

Hence, the presence of phytochemicals in the plant extracts might serve in the prevention of diabetes mellitus along with protection from free radicals produced in the body systems due to various metabolic activities.

Natural products have been used for thousands of years as folk medicine and are promising sources for novel therapeutic agents. The plants are less toxic and producing very least side effects; it is mandatory to evaluate the toxicity before using as a medicine. The lethal dosage not only designates the toxic level of a particular extract but also helps in determining the effective dosage that can be used for the experiment.

In the present study, there was no lethality or any toxic reactions found in the animals at any of the doses selected till the end of investigation period. Hence, it may be suggested that the ethanolic extracts of leaf and fruit of T. dioica and leaf of $C$. ternatea were non-toxic or safe up to $2000 \mathrm{mg} / \mathrm{kg}$ bw.

In the present OGTT study, at $3 \mathrm{~h}$, the blood glucose level was increased to a peak of $67.29 \%$ in STZ-induced diabetic rats when compared to normal control rats. The study also indicated that the ethanolic extracts of leaf and fruit of $T$. dioica and leaf of $C$. ternatea-treated groups produced a fall in the blood glucose level to $65.33 \%, 67.41 \%$, and $66.6 \%$, respectively, at $3 \mathrm{~h}$ when compared to diabetic rats. The extracts might be enhancing glucose utilization, so OGTT was significantly decreased in glucose-loaded rats.

In the present study, the STZ-induced diabetic rats (Group II) elicited significant rise in blood glucose to a level of $62.92 \%$ compared to normal control rats (Group I). On the contrary, diabetic rats treated with ethanolic extracts of individual and combined extracts of leaf and fruit of T. dioica and leaf of $C$. ternatea and standard drug glibenclamide for 28 days, exhibited decrease in blood glucose level. It was observed that ethanolic extracts reversed these effects in diabetic animals.

STZ-induced diabetes exhibit most of the diabetic complications mediated through oxidative stress involving in pancreatic cell destruction. Flavonoids have been documented to possess potent antioxidant and free radical scavenging effect [30]. The ethanolic extracts contain phytochemicals such as flavonoids, total phenolics, tannins, glycosides, and alkaloids which might have played an important role in reduction of oxidative stress of pancreatic $\beta$-cells. This might have led to increased glucose metabolism.
LPO is a free radical-mediated process leading to the oxidative decline of polyunsaturated lipids [31]. It is a highly destructive process and induces an alteration in structure and functions of cellular membranes. It is measured by TBARS which is an index of malondialdehyde production.

The results of the present study showed increased LPO on serum, liver, and kidney of STZ-induced diabetic rats. This may be due to relatively high concentration of early peroxidizable fatty acids contained by the tissues. It has been proved that hyperglycemia generates oxidative stress leading to the development of diabetic complications [4]. The increased LPO in the diabetic animals may be due to the observed remarkable increase in the concentration of TBARS and hydroperoxides in the liver and kidney of diabetic rats [32]

Hyperglycemia results in free radical formation through various biochemical reactions. The tremendous increase in LPO was observed in diabetic rats is attributed to chronic hyperglycemia. It causes increased production of ROS due to auto-oxidation of monosaccharides, which leads to the production of superoxide and hydroxyl radicals. This, in turn, causes tissue damage by reacting with polyunsaturated fatty acids in the membrane [33]. In diabetes, hypoinsulinemia increases the activity of the enzyme, fatty acyl-coenzyme A oxidase, which initiates $\beta$-oxidation of fatty acids, also results in LPO. Increased LPO impairs membrane functions by decreasing membrane fluidity and changing the activity of membrane-bound enzymes and receptors. Peroxidation of membrane lipids associated with increased membrane rigidity and reduced cells survival has been implicated in diabetes mellitus [34].

In the present study, the levels of LPO was found significantly reduced after the supplementation with the ethanolic extracts of $T$. dioica (leaf and fruit) and C. ternatea (leaf) and glibenclamide. This indicated that plants extracts inhibited oxidative damage due to the antiperoxidative effect of ingredients present in them.

There are three main antioxidant enzymes such as SOD, CAT, and GPx.

SOD has been postulated as one of the most important enzymes in the enzymatic antioxidant defense system which catalyzes the dismutation of superoxide radicals to produce $\mathrm{H}_{2} \mathrm{O}_{2}$ and molecular oxygen which can be rapidly converted to water by CAT and GPx, thereby diminishing the toxic effects caused by the radicals [35]. In the present study, a significant decline in the activity of SOD in serum and tissues of STZinduced diabetic rats was found when compared with control rats.

STZ-induced hyperglycemia provoked the generation of superoxide and hydroxyl radicals, this induced various injuries in surrounding organs and plays an important role in several clinical disorders. The decrease in SOD activity in diabetic control rats could result from inactivation by $\mathrm{H}_{2} \mathrm{O}_{2}$ or by glycation of the enzyme or by induced oxidative stress which in turn causes LPO [36].

CAT is widely distributed in all animal tissues, and its highest activity is found in the red cells and liver. It catalyzes the decomposition of $\mathrm{H}_{2} \mathrm{O}_{2}$ generated by the activity of SOD into less reactive gaseous oxygen and water molecule [37]. Therefore, the reduction in the activity of this enzyme may result in a number of deleterious effects.

In the present study, a significant reduction in the activity of CAT in serum and tissues of diabetic control rats suggested that there is an increased endogenous production of superoxide radicals and hydrogen peroxides which could inactivate and reduce the enzyme level. It could also be due to glycation of enzyme. $\mathrm{H}_{2} \mathrm{O}_{2}$ is toxic by itself and can be a precursor of other toxic species. It can react with $\mathrm{O}_{2}{ }^{--}$to form ${ }^{\circ} \mathrm{OH}$ and results in increased LPO and hence higher TBARS level. The ${ }^{\circ} \mathrm{OH}$ radical is also thought to be the primary reactive molecule in the redox activation of enzymes [38].

GPx is a general name of enzyme family with peroxidase activity whose main biological role is to protect the organisms from oxidative damage. 
It plays a primary role in the reduction of $\mathrm{H}_{2} \mathrm{O}_{2}$ in the presence of GSHforming oxidized glutathione and other hydroperoxides including lipid peroxides, thereby protecting cell protein and membrane from oxidative stress. GPx activity is also reduced in diabetic condition. $\mathrm{O}_{2}{ }^{--}$reacts with selenium at the active site of GPx and thereby inactivating the enzyme [39]. It might be also due to insufficient availability of reduced glutathione.

The plant extract- and glibenclamide-treated groups (Group IIIGroup XI) demonstrated a significant increase in the serum, hepatic, and kidney SOD, CAT, and GPx activities. Any compound with rich antioxidant properties might contribute toward the partial or total alleviation of organ damage. Therefore, removal of superoxide and hydroxyl radicals was probably one of the effective defenses of a living body against diseases [40].

The antioxidant property was evidently exhibited in the ethanolic extracts of leaf and fruit of $T$. dioica and leaf of $C$. ternatea against oxygen free radicals. This means that the flavonoids, glycosides and phenolic compounds present in the plant extracts might have reduced the glycation of enzymes, reduced the oxidative stress (free radicals scavenging activity), detoxified the endogenous metabolic peroxides generated by STZ, or they may reduce free radical-related diseases and improve the activities of the antioxidant enzymes. Glibenclamide also showed increase in antioxidant enzymes which was due to its hypoglycemic effects.

In the present study, increased activities of SOD, CAT, and GPx in the serum, liver, and kidney of diabetic rats confirm that the investigated drugs do extend a clear protection against LPO in STZ-induced diabetic rats.

\section{CONCLUSION}

The present study clearly concluded that the ethanolic extracts of T. dioica (leaf and fruit) and C. ternatea (leaf) possess ability to control blood glucose in diabetes and free radical scavenging property has potential to prevent diabetic associated complications. Our current investigation supports the traditional use of T. dioica (leaf and fruit) and C. ternatea (leaf) in the treatment of diabetes.

\section{CONFLICT OF INTEREST}

None.

\section{REFERENCES}

1. American Diabetes Association. Diagnosis and classification of diabetes mellitus. Diabetes Care 2008;31:S55-60.

2. International Diabetes Federation. IDF Diabetes Atlas. $5^{\text {th }}$ ed. Brussels: IDF; 2016.

3. International Diabetes Federation. IDF Diabetes Atlas. $4^{\text {th }}$ ed. Brussels: International Diabetes Federation; 2011.

4. Baynes JW. Role of oxidative stress in development of complications in diabetes. Diabetes 1991;40:405-12.

5. Halliwell B, Gutteridge JM. Role of free radicals and catalytic metal ions in human disease: An overview. Methods Enzymol 1990;186:1-85.

6. Genet S, Kale RK, Baquer NZ. Alterations in antioxidant enzymes and oxidative damage in experimental diabetic rat tissues: Effect of vanadate and fenugreek (Trigonellafoenum graecum). Mol Cell Biochem 2002;236:7-12

7. Chauhan S, Kaur A, Vyas M, Khatik GL. Comparison of antidiabetic and antioxidant activity of wild and cultivated variety of Rauwolfia serpentina. Asian J Pharm Clin Res 2017;10:404-6.

8. Osawa T. Mechanisms of Ageing and Development. Vol. 3. Seattle, Washington, USA: Elsevier; 1999. p. 133-9.

9. Ogugua $\mathrm{VN}$, Egba SI, Adoga JE. In vivo antioxidant and antihyperglycaemic properties of aqueous extract of a herbal cocktail. World J Pharm Pharm Sci 2013;2:890-5.

10. Kirtikar KR, Basu BD. Indian Medicinal Plants. $2^{\text {nd }}$ ed., Vol. 2. Allahabad: Jayyed Press; 1975. p. 1110-1.

11. Som MG, Maity TK, Hazra P. Pointed Gourd. In: Kallo G, Berg BO, editors. Genetic Improvement of Vegetable Crops. Oxford, UK: Pergamon Press; 1993

12. Asolkar LV, Kakkar KK, Chakre OJ. Second supplement to glossary of Indian medicinal plants with active principles. Part I (A-K) (19651981). New Delhi: Publications \& Information Directorate, CSIR; 1992. p. 134-5.

13. Kavitha R, Premalakshmi V. Studies on the synergetic effect of Trichosanthes dioica and Clitoria ternatea leaf extract on the streptozotocin-induced diabetic rats. Int J Res Pharm Biomed Sci 2012;3:1056-64.

14. Kavitha R. Evaluation of hypoglycemic effect of ethanolic extracts of leaf and fruit of $T$. dioica and leaf of $C$. ternatea in streptozotocin induced diabetic rats. Int J Pharm Biol Sci 2014;5:1061-8.

15. Mukherjee PK, Kumar V, Kumar NS, Heinrich M. The ayurvedic medicine clitoria ternatea from traditional use to scientific assessment. J Ethanopharmacol 2008;120:291-301.

16. Parrotta JA. Healing Plants of Peninsular India. New York: CABI Publication; 2001. p. 382-3.

17. Prajapati ND, Purohit SS, Sharma AK, Kumar TA. Handbook of Medicinal Plants: A Complete Source Book. Jodhpur, India: Agrobios Publication; 2003. p. 154-5.

18. Khare CP. Encyclopedia of Indian Medicinal Plants. New York: Springer Publishing Company; 2004. p. 153-4.

19. Kapoor LD. Handbook of Ayurvedic Medicinal Plants. Boca Raton, FL, USA: CRC Press; 2005. p. 126-7.

20. Fantz PR. Ethnobotany of Clitoria (Leguminosae). Economic Botany. Vol. 45. New York: Botanical Garden Press; 1991. p. 511-20.

21. Anonymous. Phytochemical Investigation of Certain Medicinal Plants Used in Ayurveda. New Delhi: Central Council for Research in Ayurveda and Siddha; 1990.

22. Kumar GP, Arulselvan P, Kumar DS, Subramanian SP. Antidiabetic activity of fruits of Terminalia chebula on streptozotocin induced diabetic rats. J Health Sci 2006a;52:283-91.

23. Sasaki T, Matsuy S, Sanae A. Effect of acetic acid concentration on the colour reaction in the O-toluidine boric acid method for blood glucose determination. Ransho Kagajci 1972;1:346-50.

24. Mihara M, Uchiyama M. Determination of malonaldehyde precursor in tissues by thiobarbituric acid test. Anal Biochem 1978;86:271-8.

25. Kakkar P, Das B, Viswanathan PN. A modified spectrophotometric assay of superoxide dismutase. Ind J Biochem Biophysics 1984;21:130- 2

26. Sinha AK. Colorimetric assay of catalase. Anal Biochem 1972;47:389- 94

27. Beutler E, West C, Beutler B. Electrophoretic polymorphism of glutathione peroxidase. Ann Hum Genet 1974;38:163-9.

28. Kirtikar KR, Basu BD. Indian Medicinal Plants. $3^{\text {rd }}$ ed., Vol. 3. Dehradun: Singh Mahendra Pal Singh; 1980. p. 2261-2

29. Rai PK, Jaiswal D, Rai DK, Sharma B, Watal G. Effect of water extract of Trichosanthes dioica fruits in streptozotocin induced diabetic rats. Indian J Clin Biochem 2008;23:387-90.

30. Shenoy C, Patil MB, Kumar R, Patil S. Preliminary phytochemical investigation and wound healing activity of Allium cepa Linn (Liliaceae). Int J Pharm Pharm Sci 2009:2:167-75.

31. Sangeetha MS, Priyanga S, Hemmalakshmi S, Devaki K. In vivo antidiabetic potential of Cyclea peltata in streptozotocin-induceddiabetic rats. Asian J Pharm Clin Res 2015;8:103-8.

32. Mainzen Prince PS, Menon VP. Antioxidant action of Tinospora cordifolia root extract in alloxan diabetic rats. Phytother Res 2001;15:213.

33. Wolff S, Dean RT. Glucose autooxidation and protein modification. Biochem J 1987;24:243-50.

34. Selvam RS, Anuradha CV. Lipid peroxidation and antiperoxidative enzyme changes in erythrocytes in diabetes mellitus. Indian J Biochem Biophys 1988;25:268-72

35. Winterbourn CC. Concerted antioxidant activity of glutathione and superoxide dismutase. In: Packer L, Fuchs J, editors. Biothiols in Health and Disease. New York: Marcel Dekker Inc.; 1995. p. 117-34.

36. Sozmen BY, Sozmen B, Delen Y, Onat T. Catalase/superoxide dismutase $(\mathrm{SOD})$ and catalase/paraoxonase $(\mathrm{PON})$ ratio may implicate poor glycemic control. Arch Med Res 2001;32:283.

37. Gaetani G, Ferraris A, Rolfo M, Mangerini R, Arena S, Kirkman H. Predominant role of catalase in the disposal of hydrogen peroxide within human erythrocytes. Blood 1996;87:1595-9.

38. Salahudeen $A K$. Role of lipid peroxidation in $\mathrm{H}_{2} \mathrm{O}_{2}$ induced renal epithelial (LLC-pk 1) cell injury. Am J Physiol 1995;268:F30-8.

39. Blum J, Fridorich I. Inactivation of glutathione peroxidase by superoxide radical. Arch Biochem Biophys 1985;247:1-11.

40. Pushparaj P, Tan CH, Tan BK. Effects of Averrhoa bilimli leaf extract on blood glucose and lipids in streptozotocin diabetic rats. J Ethnopharmacol 2000;72:69-76. 